\title{
Ethanolic extract of Thevetia peruviana flowers enhances TNF- $\alpha$ and TRAIL-induced apoptosis of human cervical cancer cells via intrinsic and extrinsic pathways
}

\author{
CHITTIMA MANAGIT ${ }^{1}$, HIROAKI SAKURAI ${ }^{2}$ and IKUO SAIKI ${ }^{3}$ \\ ${ }^{1}$ Department of Pharmaceutical Technology, Faculty of Pharmacy, Srinakharinwirot University, Nakhonnayok 26120 , \\ Thailand; ${ }^{2}$ Department of Cancer Cell Biology, Graduate School of Medicine and Pharmaceutical Sciences; \\ ${ }^{3}$ Division of Pathogenic Biochemistry, Institute of Natural Medicine, University of Toyama, Toyama 930-0194, Japan
}

Received June 24, 2015; Accepted September 15, 2016

DOI: $10.3892 / \mathrm{ol} .2017 .5748$

\begin{abstract}
Tumor necrosis factor- $\alpha$ (TNF- $\alpha$ ) and TNF-related apoptosis-inducing ligand (TRAIL) are promising candidates for cancer treatment due to their ability to induce apoptosis through death receptor stimulation. However, their usage may be limited due to the resistance of cancer cells to TNF- $\alpha$ - and TRAIL-induced apoptosis. Currently, there is interest in screening for natural products that can sensitize cancer cells to TNF- $\alpha$ - and TRAIL-induced apoptosis for their use in combination with TNF- $\alpha$ or TRAIL. It was previously reported that the bark extract of Thevetia peruviana showed a reversal effect on TRAIL-resistance in human gastric adenocarcinoma cell lines. In the present study, the effects of the ethanolic extract of T.peruviana flowers on TNF- $\alpha$ - and TRAIL-induced apoptosis of human cervical cancer HeLa cells were investigated in vitro by determining cell viability and apoptosis using a WST-1 cell proliferation assay and immunoblot analysis, respectively. The ethanolic extract of $T$. peruviana flowers promoted TNF- $\alpha$ and TRAIL-mediated cell death through the activation of the caspase cascade, poly(ADP-ribose) polymerase and $\mathrm{BH} 3$-interacting domain death agonist cleavage. Combined treatment using the extract plus TNF- $\alpha$ resulted in downregulation of anti-apoptotic protein, including myeloid cell leukemia sequence-1, B-cell lymphoma-extra large (Bcl-XL), X-linked inhibitor of apoptosis protein and survivin, while the combined treatment with TRAIL downregulated Bcl-XL. Thus, the ethanolic extract of T.peruviana flowers has
\end{abstract}

Correspondence to: Dr Chittima Managit, Department of Pharmaceutical Technology, Faculty of Pharmacy, Srinakharinwirot University, 63 Mu 7 Rangsit-Nakhonnayok Road, Ongkharak, Nakhonnayok 26120, Thailand

E-mail: chittimm@g.swu.ac.th; jittima.jittima.m@gmail.com

Key words: B-cell lymphoma-extra large, death receptor, cardiac glycosides, HeLa cells, anti-apoptotic protein, plant extract, cervical cancer potential in sensitizing the TNF- $\alpha$ - and TRAIL-induced apoptosis of HeLa cells via the intrinsic and extrinsic pathways.

\section{Introduction}

Chemotherapy is one of the major standard treatments that is beneficial for numerous cancer types due to its efficient induction of tumor cell death by apoptosis. At present, the cancer resistance of chemotherapeutic drugs is a major drawback that leads to the failure of cancer treatments. Chemotherapeutic drugs eliminate tumor cells by the induction of apoptosis via two distinct pathways, which act through the mitochondria (intrinsic signaling pathway) or through death receptors on the cell surface (extrinsic signaling pathway) (1). Induction of apoptosis via the intrinsic signaling pathway is initiated by severe cell stress, including DNA damage, mitotic catastrophe, hypoxia and cell cycle checkpoint defects. The majority of conventional chemotherapeutic drugs trigger DNA damage and induce apoptosis via the intrinsic signaling pathway by the activation of tumor suppressor protein, p53, which leads to the breakdown of mitochondrial membrane and the release of cytochrome $c$ into the cytosol. Cytochrome $c$ binds to the adaptor apoptotic protease activating factor 1, forming an apoptosome. The apoptosome subsequently activates caspase- 9 and caspase-3, which results in the cleavage of death substrates (2-4). Defects in intrinsic apoptosis signal transduction, such as the mutation of p53, contributes to the chemotherapeutic drug resistance of cancer $(5,6)$. The extrinsic pathway triggers apoptosis independently on tumor suppressor p53 through the binding of death ligand to the death receptors, including Fas, tumor necrosis factor receptor 1 (TNF-R1) or TNF-related apoptosis-inducing ligand (TRAIL) receptors $(7,8)$.

Tumor necrosis factor- $\alpha($ TNF- $\alpha)$ and TRAIL are death ligands that effectively activate various apoptosis signal transductions after their binding to TNF-R1 and TRAIL receptors, respectively. Binding of TNF- $\alpha$ to TNF-R1 recruits the adaptor molecules, which are TNF-R1-associated death domain protein (TRADD) and Fas-associated death domain (FADD) to activate a caspase cascade from the upstream initiator caspase- 8 to the downstream effector caspase-3 $(9,10)$. TRAIL induces 
apoptosis through its activation with two distinct receptors, DR4 and DR5, leading to the direct recruitment of FADD and subsequent activation of caspase- 8 and caspase- $3(9,11,12)$. The intrinsic and extrinsic pathways connect their signal transductions through the pro-apoptotic $\mathrm{BH} 3$-interacting domain death agonist (Bid), which is a member of the apoptosis regulator B-cell lymphoma 2 (Bcl-2) family. The cytosolic Bid is cleaved by the activated caspase- 8 to generate the truncated form of Bid, which translocates to the mitochondria and mediates cytochrome $c$ release via direct interaction with $\mathrm{Bcl}-2$ homologous antagonist killer and Bcl-2-associated protein. This mechanistic link apparently amplifies the apoptosis signal following death receptor activation by activating downstream effector caspases (13-15). Effector caspases, including caspase-3 and caspase-7, are responsible for the cleavage of cellular proteins such as poly(ADP-ribose) polymerase (PARP), which are involved in DNA repair and programmed cell death (16). PARP is inactivated by caspase- 3 cleavage, which ultimately causes morphological and biochemical changes, and apoptotic cell death (17). Anti-apoptotic proteins, such as myeloid cell leukemia sequence-1 (Mcl-1), B-cell lymphoma-extra large (Bcl-XL), X-linked inhibitor of apoptosis protein (XIAP) and survivin can block caspase cascades $(18,19)$.

Presently, TNF- $\alpha$ and TRAIL are being investigated in clinical trials for cancer therapy. TRAIL is a promising anticancer agent, as it can induce the apoptosis of cancer cells without toxic effects on normal cells (11). However, TNF- $\alpha$ and TRAIL resistance have been observed in a number of cancer cell lines, which may be due to the defect in their receptor signaling or the dysfunction of anti-apoptotic proteins controlled by survival signaling pathways (9-11). Currently, there is much interest in screening for agents that overcome TNF- $\alpha$ and TRAIL resistance for use in combination with TNF- $\alpha$ and TRAIL during cancer treatment $(20,21)$.

Thevetia peruviana (also known as rumpei in Thai) is a native plant of Central and South America, belonging to the Apocynaceae family. This plant has been grown as a decorative shrub throughout the tropical and subtropical parts of the world, including Thailand, due to its beautiful flowers. T. peruviana has a dense crown, diffuse branches and linear, willow-like, dark-green, glossy leaves. The colors of the flowers vary from yellow to a dull orange. The fruit is a fleshy, triangular drupe with 2 seeds. The fruit color is green, which turns to yellow after ripening. The sap is milky white (22). All parts of T. peruviana are poisonous to man and animals due to their major phytochemical cardiac glycosides, including thevetin A, thevetin B and acetylthevetin, found in the seed kernels, the leaves, the fruit and the sap $(22,23)$. In addition, phenolics and flavonoids are found in different parts of T.peruviana. Phenolics and flavonoids levels are high in the leaves and flowers, respectively (24). Despite its toxicity, this plant has been reported to promote various biological activities. For example, terpenes isolated from the seed extract exhibited antifungal properties against Cladosporium cucumerinum (25), and flavonols isolated from the leaf extract promoted human immunodeficiency virus type 1 (HIV-1) reverse transcriptase and HIV-1 integrase inhibitory activities (26). Furthermore, a previous study found that thevefolin cardenolide glycoside isolated from the bark extract of T. peruviana showed a reversal effect on TRAIL-resistance in human gastric adenocarcinoma cell lines through the enhancement of mRNA expression of death receptors, DR4 and DR5 (27). Therefore, bioactive compounds from other parts of $T$. peruviana, such as the flowers and leaves, may possess anticancer activity. Currently, there are no studies concerning the anticancer effect of the constituents from T. peruviana flowers. Therefore, the investigation of their anticancer effects and the study of the mechanisms of action may be inciteful.

In the present study, the effects of an ethanolic extract of T.peruviana flowers on TNF- $\alpha$ - and TRAIL-induced apoptosis were investigated in a TRAIL-resistant human cervical cancer cell line. The mechanisms of action behind the apoptotic and anti-apoptotic proteins involved in the intrinsic and extrinsic pathways of apoptosis were also studied.

\section{Materials and methods}

Plant extract. Flowers of T. peruviana were collected from Nakhonnayok, Thailand. Plant samples were identified by Dr Vipaporn Sareedenchai from the Department of Pharmacognosy, Faculty of Pharmacy, Srinakharinwirot University (Nakhonnayok, Thailand). The petals of the samples were separated from the flowers, and then cleaned and dried in a hot air oven at $50^{\circ} \mathrm{C}$ for $6 \mathrm{~h}$. The dried plant material was ground using a chopping electronic mill (sieve no. 20). The powder of the flower was macerated with $95 \%$ ethanol (plant to solvent ratio of 1:20 w/v; Sigma-Aldrich; EMD Millipore, Billerica, MA, USA) at room temperature for 7 days and filtered using Whatman filter paper no. 1. The extraction procedure was repeated by adding $95 \%$ ethanol into the remaining damp flower powder mass, with a maceration time of 3 days. The filtrates were collected and evaporated under reduced pressure until dry. The yield of the extract was $43.43 \%$ by weight of dry plant powder. The obtained flower extract of T. peruviana was dissolved in dimethyl sulfoxide (DMSO; Sigma-Aldrich; EMD Millipore) to create a stock solution, which was kept at $-20^{\circ} \mathrm{C}$ until use. The final concentration of DMSO in all tested assays was $<0.1 \%$. The flower extract was tested for its effect on cell viability in a human cervical cancer cell line using a cell viability assay, and the possible mechanisms of action via the associated apoptotic and anti-apoptotic proteins were determined using immunoblot analysis.

Antibodies and reagents. Recombinant human TNF- $\alpha$ and TRAIL were purchased from Peprotech EC, Ltd. (London, UK). Primary antibodies specific to caspase-9, caspase-8, caspase-3, PARP, Bid, Mcl-1, Bcl-XL, XIAP and survivin were obtained from Cell Signaling Technology, Inc. (Danvers, MA, USA). Primary antibodies specific to actin were obtained from Santa Cruz Biotechnology, Inc. (Dallas, TX, USA).

Cell culture. Human cervical cancer HeLa cells (ATCC, Rockville, MD, USA) were cultured in Dulbecco's modified Eagle's medium (DMEM; Gibco; Thermo Fisher Scientific, Inc., Waltham, MA, USA) supplemented with $10 \%$ heat-inactivated fetal calf serum, $100 \mathrm{U} / \mathrm{ml}$ penicillin and $100 \mu \mathrm{g} / \mathrm{ml}$ streptomycin (all Gibco; Thermo Fisher Scientific, Inc.). The culture was maintained at $37^{\circ} \mathrm{C}$ in a humidified atmosphere of $5 \%$ $\mathrm{CO}_{2}$. 
Cell viability assay. The viabilities of the HeLa cells with and without the treatment of an ethanolic extract of T. peruviana flowers were determined using the WST-1 Cell Counting kit (Wako Pure Chemical Industries, Osaka, Japan). The assay principle is based on the cleavage of a tetrazolium salt into a formazan product by the living cell enzymes, particularly mitochondrial dehydrogenase $(28,29)$. Briefly, the HeLa cells were seeded into a 96 -well plate $\left(6 \times 10^{3}\right.$ cells/100 $\mu \mathrm{l} /$ well $)$ in culture medium and incubated at $37^{\circ} \mathrm{C}$ in a humidified atmosphere of $5 \% \mathrm{CO}_{2}$ for $24 \mathrm{~h}$. Following incubation, the cells were pretreated with various concentrations $(3,10,30,100$ and $300 \mu \mathrm{g} / \mathrm{ml}$ ) of the ethanolic extract of T. peruviana flowers (100 $\mu \mathrm{l}$; or $0.1 \%$ DMSO in culture medium as a control) for $30 \mathrm{~min}$, and then the aliquots of TNF- $\alpha$ or TRAIL in culture medium $(5 \mu \mathrm{l})$ were added to each well (final concentration of $20 \mathrm{ng} / \mathrm{ml}$ for TNF- $\alpha$ or $200 \mathrm{ng} / \mathrm{ml}$ for TRAIL). The cells were then further incubated for $24 \mathrm{~h}$. WST-1 solution $(10 \mu \mathrm{l})$ was added to each well $2 \mathrm{~h}$ prior to the determination of the absorbance at the maximum wavelength of $450 \mathrm{~nm}$ by microplate reader. The assay was performed in triplicate. The effect of the ethanolic extract of T. peruviana flowers on HeLa cell viability was calculated from the absorbance of soluble formazan dye generated by living cells and the results were expressed as the percentage of cell viability compared with the control.

Immunoblotting. Immunoblot analysis was performed as previously described (30). HeLa cells were seeded and grown overnight in a 6 -well plate $\left(1 \times 10^{6} / 2 \mathrm{ml} /\right.$ well $)$ in culture medium. After treatment, the cells were scraped and lysed by whole-cell lysis buffer [25 mM HEPES ( $\mathrm{pH} 7.7)$, $300 \mathrm{mM} \mathrm{NaCl}, 1.5 \mathrm{mM} \mathrm{MgCl}_{2}, 0.2 \mathrm{mM}$ EDTA, $0.1 \%$ Triton X-100, $20 \mathrm{mM}$ b-glycerophosphate, $1 \mathrm{mM} \mathrm{Na} \mathrm{VO}_{4}$, $1 \mathrm{mM}$ phenylmethylsulfonyl fluoride, $1 \mathrm{mM}$ dithiothreitol, $10 \mu \mathrm{g} / \mathrm{ml}$ aprotinin and $10 \mu \mathrm{g} / \mathrm{ml}$ leupeptin). The cell lysates were subjected to electrophoresis in 7.5 or $10 \%$ SDS-PAGE, and electrophoretically transferred to Immobilon-P nylon membranes (Millipore, Bedford, MA, USA). The membranes were blocked with BlockAce (Dainippon Pharmaceutical, Co., Ltd., Osaka, Japan) for at least 2 h, washed three times for $10 \mathrm{~min}$ each with PBS/Tween-20 (0.1\% v/v) buffer and incubated overnight at $4{ }^{\circ} \mathrm{C}$ with primary antibodies against caspase-9 (1:1,000 dilution; catalog no. 9504; Cell Signaling Technology, Inc.), caspase-8 (0.7:1,000 dilution; catalog no. 9746; Cell Signaling Technology, Inc.), caspase-3 (1:1,000 dilution; catalog no. 9662; Cell Signaling Technology, Inc.), PARP (1:1,000 dilution; catalog no. 9542; Cell Signaling Technology, Inc.), Bid (1:1,000 dilution; catalog no. 2002; Cell Signaling Technology, Inc.), Mcl-1 (1:1,000 dilution; catalog no. 4572, Cell Signaling Technology, Inc.), Bcl-XL (1:1,000 dilution; catalog no. 2764; Cell Signaling Technology, Inc.), XIAP (1:1,000 dilution; catalog no. 2045; Cell Signaling Technology, Inc.) and survivin (1:1,000 dilution; catalog no. 2803; Cell Signaling Technology, Inc.). Actin (1:1,000 dilution; catalog no. sc-1615; Santa Cruz Biotechnology, Inc.) served as a control. Subsequently, membranes were washed three times for 10 min each with PBS/Tween-20 $(0.1 \% \mathrm{v} / \mathrm{v})$ buffer and then incubated with horseradish peroxidase-conjugated goat anti-rabbit secondary antibodies (1:2,000 dilution; catalog no. P0448; Dako; Agilent Technologies, Inc., Santa Clara, CA, USA) at room temperature

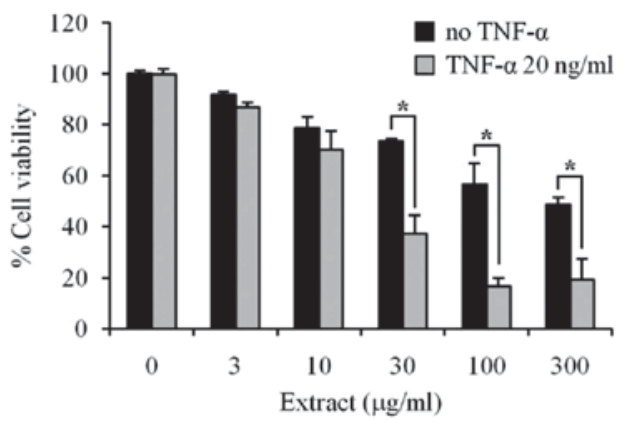

Figure 1. Effect of the ethanolic extract of Thevetia peruviana flowers on TNF- $\alpha$-induced cell death. HeLa cells were pretreated with the extract for $30 \mathrm{~min}$, and further incubated with and without TNF- $\alpha(20 \mathrm{ng} / \mathrm{ml})$ for $24 \mathrm{~h}$, after which cell viability was determined using the WST-1 Cell Counting kit. Data are expressed as the mean \pm standard deviation from three independent experiments. ${ }^{*} \mathrm{P}<0.01$. TNF- $\alpha$, tumor-necrosis factor- $\alpha$.

for $1 \mathrm{~h}$. Following incubation, membranes were washed three times for $10 \mathrm{~min}$ each and the electrophoretic bands were visualized using enhanced chemiluminescence reagents (GE Healthcare Life Sciences, Chalfont, UK), according to the manufacturer's protocol.

Statistical analysis. The results are expressed as the mean \pm standard deviation. An independent sample t-test was used to compare mean values, and a least significant difference test was applied using SPSS software version 13.0 (SPSS, Inc., Chicago, IL, USA). P<0.01 was used to indicate a statistically significant difference.

\section{Results}

Ethanolic extract of $T$. peruviana flowers enhances TNF- $\alpha$-induced apoptosis in human cervical cancer cells. Initially, the effect of the ethanolic extract of $T$. peruviana flowers on TNF- $\alpha$-induced cell death was examined in HeLa cells. Pretreatment with the ethanolic extract of T. peruviana flowers at various concentrations $(3-300 \mu \mathrm{g} / \mathrm{ml})$ for $30 \mathrm{~min}$, followed by TNF- $\alpha$ stimulation for $24 \mathrm{~h}$, enhanced TNF- $\alpha$-induced cell death. The viability of the HeLa cells treated with $20 \mathrm{ng} / \mathrm{ml}$ of TNF- $\alpha$ for $24 \mathrm{~h}$ was $99.62 \%$ compared with the control, which was treated with medium alone. HeLa cell viabilities after treatment with the combination of TNF- $\alpha$ and the ethanolic extract of T. peruviana flowers at the concentrations of $3-300 \mu \mathrm{g} / \mathrm{ml}$ were in the range of $16-87 \%$. This result indicated that the ethanolic extract of $T$. peruviana flowers promoted cell death in the range of $13-84 \%$. The combination treatment of TNF- $\alpha$ and the ethanolic extract of T. peruviana flowers at the concentrations of 30, 100 and $300 \mu \mathrm{g} / \mathrm{ml}$ significantly enhanced TNF- $\alpha$-induced cell death, with cell viability of $37.17,16.65$, and $19.18 \%$, respectively (Fig. 1). However, the ethanolic extract of T. peruviana flowers alone at the concentration of $300 \mu \mathrm{g} / \mathrm{ml}$ showed the highest toxicity to the HeLa cells (Fig. 1). The ethanolic extract of $T$. peruviana flowers at the concentration of $100 \mu \mathrm{g} / \mathrm{ml}$ was selected for further studies, as it was the minimum concentration that significantly increased the percentage of cell death $>80 \%$ when combined with TNF- $\alpha$, while the extract alone had less toxicity to HeLa cells (Fig. 1). In addition, the ethanolic extract of T. peruviana 
A

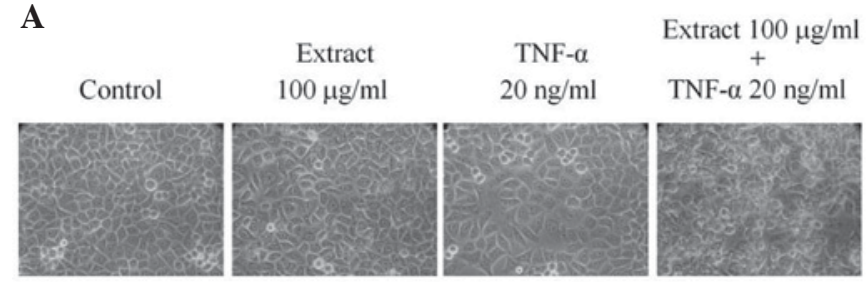

B

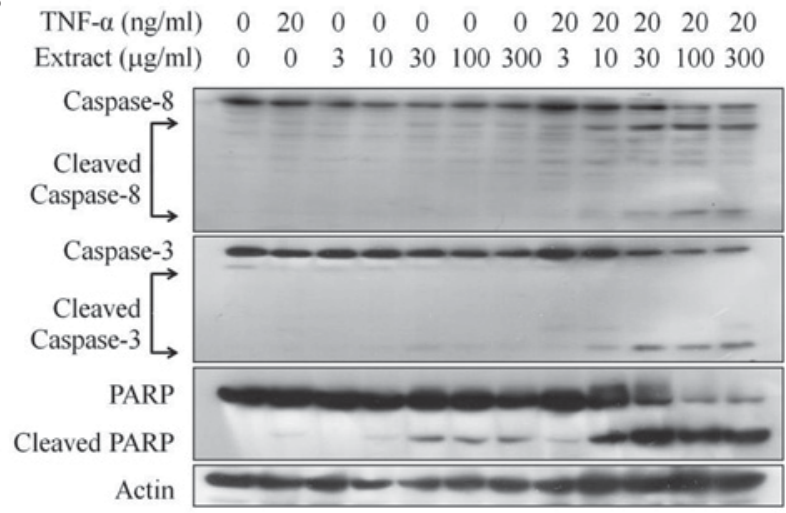

Figure 2. Enhancement of TNF- $\alpha$-induced apoptosis by the ethanolic extract of Thevetia peruviana flowers. HeLa cells were pretreated with the extract $(100 \mu \mathrm{g} / \mathrm{ml})$ for $30 \mathrm{~min}$, and further incubated in the presence or absence of TNF- $\alpha(20 \mathrm{ng} / \mathrm{ml})$ for $12 \mathrm{~h}$. (A) Images were captured under a microscope at an original magnification of $x 40$. (B) Whole cell lysates were analyzed by immunoblot for apoptotic proteins, caspase- 8 and -3 , and PARP, using actin as the loading control. TNF- $\alpha$, tumor-necrosis factor- $\alpha$; PARP, poly(ADP-ribose) polymerase.
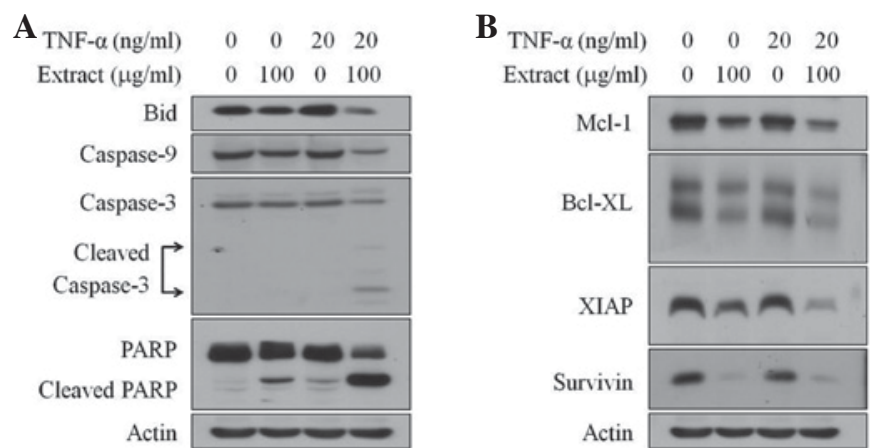

Figure 3. Inhibitory effect of the ethanolic extract of Thevetia peruviana flowers on apoptotic and anti-apoptotic proteins. HeLa cells were pretreated with the extract $(100 \mu \mathrm{g} / \mathrm{ml})$ for $30 \mathrm{~min}$, and further incubated in the presence or absence of TNF- $\alpha(20 \mathrm{ng} / \mathrm{ml})$ for $12 \mathrm{~h}$. (A) Whole cell lysates were analyzed by immunoblot for apoptotic proteins, Bid, caspase- 9 and-3, and PARP. (B) Whole cell lysates were analyzed by immunoblotting for anti-apoptotic proteins Mcl-1, Bcl-XL, XIAP and survivin using actin as a loading control. TNF- $\alpha$, tumor-necrosis factor- $\alpha$; PARP, poly(ADP-ribose) polymerase; Mcl-1, myeloid cell leukemia sequence-1; Bcl-XL, B-cell lymphoma-extra large; XIAP, X-linked inhibitor of apoptosis protein.

flowers at the concentration of $100 \mu \mathrm{g} / \mathrm{ml}$ was able to cause massive cell death (Fig. 2A) and cleavage of apoptotic proteins, caspase- 8 and -3 , and PARP in the HeLa cells at $12 \mathrm{~h}$ when treated with TNF- $\alpha$ (Fig. 2B).

TNF- $\alpha$ sensitization effect of the ethanolic extract of T. peruviana flowers contributes through the activation of the caspase cascade. To confirm the activation of apoptosis

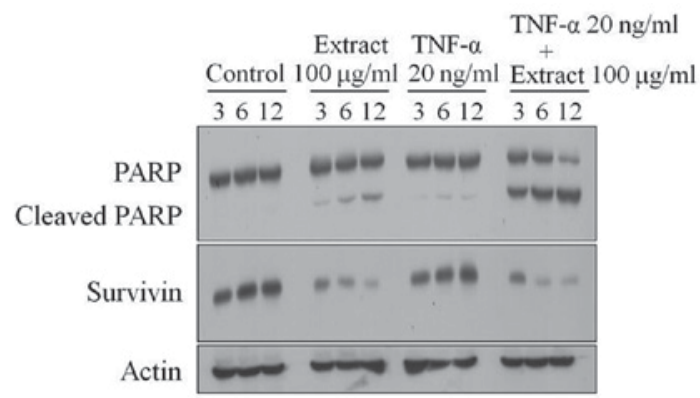

Figure 4. Time-dependent decrease in survivin level by the treatment of the ethanolic extract of Thevetia peruviana flowers. HeLa cells were pretreated with the extract $(100 \mu \mathrm{g} / \mathrm{ml})$ for $30 \mathrm{~min}$, and further incubated with and without TNF- $\alpha(20 \mathrm{ng} / \mathrm{ml})$ for 3,6 and $12 \mathrm{~h}$. Whole cell lysates were analyzed by immunoblotting for the anti-apoptotic protein survivin using actin as a loading control. TNF- $\alpha$, tumor-necrosis factor- $\alpha$; PARP, poly(ADP-ribose) polymerase.

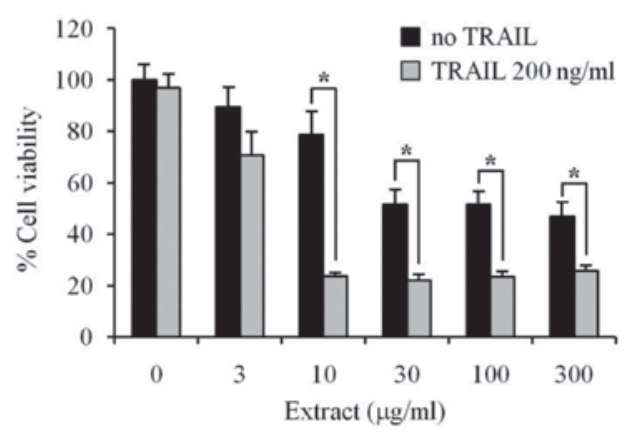

Figure 5. Effect of the ethanolic extract of Thevetia peruviana flowers on TRAIL-induced cell death in HeLa cells. Cells were pretreated with the extract for $30 \mathrm{~min}$, and further incubated with and without TRAIL $(200 \mathrm{ng} / \mathrm{ml})$ for $24 \mathrm{~h}$, after which cell viability was determined using the WST-1 Cell Counting kit. Data are expressed as the mean \pm standard deviation from three independent experiments. ${ }^{*} \mathrm{P}<0.01$. TNF- $\alpha$, tumor-necrosis factor- $\alpha$; TRAIL, TNF-related apoptosis-inducing ligand.

signals by the combination treatment of the ethanolic extract of T. peruviana flowers and TNF- $\alpha$, western blot analysis of the cleavage of PARP, Bid and caspase- $8,-9$ and -3 , which are hallmarks of cells undergoing apoptosis, was performed in HeLa cells treated with the extract and/or TNF- $\alpha$. Pretreatment with the ethanolic extract of T. peruviana flowers at the concentrations of 100 and $300 \mu \mathrm{g} / \mathrm{ml}$ markedly enhanced TNF- $\alpha$-induced apoptosis, as clearly shown by the increase in the cleavage of caspase- $8,-3$ and -9 , Bid and PARP (Figs. 2B and 3A). These results indicated that the ethanolic extract of T. peruviana flowers sensitized the TNF- $\alpha$-induced apoptosis of HeLa cells through the death receptor and the mitochondria-dependent pathways. In addition, the ethanolic extract of $T$. peruviana flowers exhibited a synergistic effect on TNF- $\alpha$-induced apoptosis in a dose-dependent manner (Fig. 2B).

Downregulation of anti-apoptotic proteins mediates the TNF- $\alpha$ sensitization effect of the ethanolic extract of $T$. peruviana flowers. The effects of the ethanolic extract of $T$. peruviana flowers on the levels of several anti-apoptotic proteins, including Mcl-1, Bcl-XL, XIAP and survivin, in HeLa cells treated with the extract and/or TNF- $\alpha$ were examined. The 

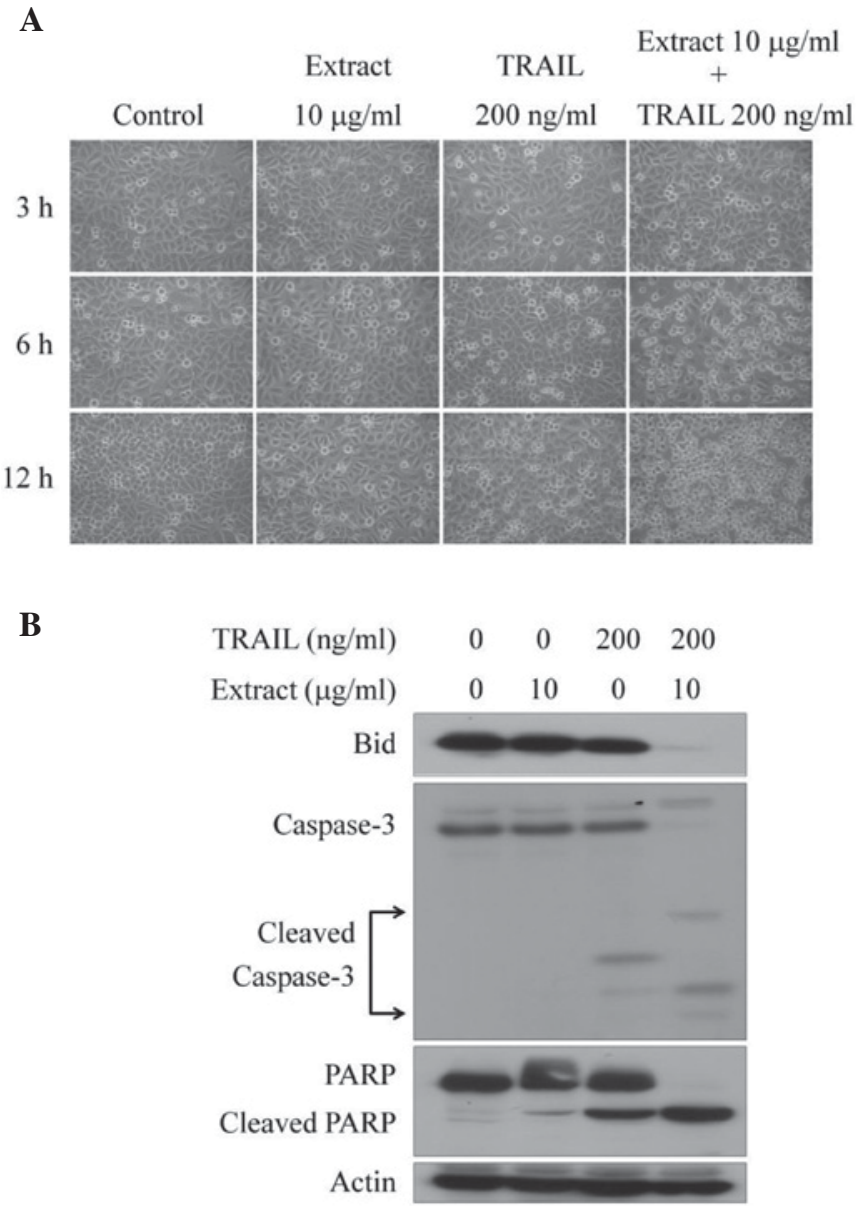

Figure 6. Enhancement of TRAIL-induced apoptosis by the ethanolic extract of Thevetia peruviana flowers. (A) HeLa cells were pretreated with the extract $(10 \mu \mathrm{g} / \mathrm{ml})$ for $30 \mathrm{~min}$, and further incubated with and without TRAIL (200 ng/ml) for 3,6 and $12 \mathrm{~h}$. Images were captured at an original magnification of $x 20$. (B) Whole cell lysates at $12 \mathrm{~h}$ were analyzed by immunoblotting for the apoptotic proteins Bid, caspase-3, and PARP, using actin as a loading control. TNF- $\alpha$, tumor-necrosis factor- $\alpha$; PARP, poly(ADP-ribose) polymerase; TRAIL, TNF-related apoptosis-inducing ligand.

results showed that the ethanolic extract of T.peruviana flowers at the concentration of $100 \mu \mathrm{g} / \mathrm{ml}$ alone or in combination with TNF- $\alpha$ decreased the expression of the observed anti-apoptotic proteins. The expression of the anti-apoptotic proteins Mcl-1, Bcl-XL and XIAP was markedly decreased by the combination treatment of the ethanolic extract of T. peruviana flowers and TNF- $\alpha$, while the expression of the anti-apoptotic protein survivin was almost completely silenced at $12 \mathrm{~h}$ of treatment (Fig. 3B). In addition, the combination treatment of the ethanolic extract of T. peruviana flowers and TNF- $\alpha$ reduced the expression of anti-apoptotic protein survivin in the early state at 3 and $6 \mathrm{~h}$ of incubation (Fig. 4). These results indicated that the ethanolic extract of $T$. peruviana flowers sensitized TNF- $\alpha$-induced apoptosis by regulating the downregulation of anti-apoptotic proteins Mcl-1, Bcl-XL, XIAP and survivin, and that the sensitization was continuous for $12 \mathrm{~h}$.

Ethanolic extract of $T$. peruviana flowers enhances TRAIL-induced apoptosis in human cervical cancer cells. Since the ethanolic extract of $T$. peruviana flowers enhanced TNF- $\alpha$-induced apoptosis in the HeLa cells, the

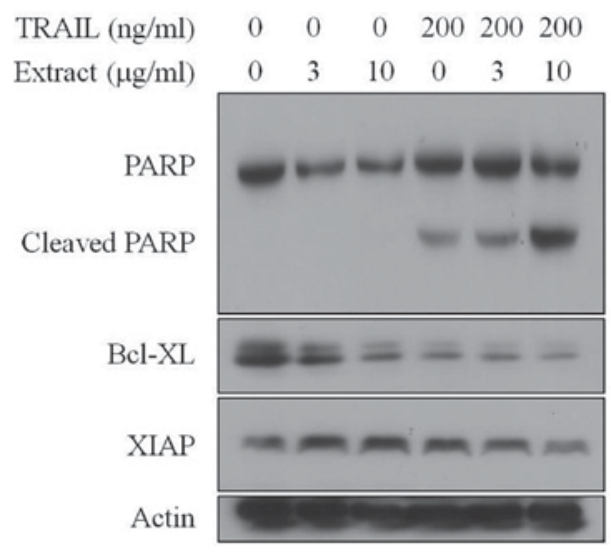

Figure 7. Correlation of the dose-dependent decrease in Bcl-XL level by the ethanolic extract of Thevetia peruviana flowers. HeLa cells were pretreated with the extract for $30 \mathrm{~min}$, and further incubated with and without TRAIL (200 ng/ml) for $3 \mathrm{~h}$. Whole cell lysates were analyzed by immunoblotting for the anti-apoptotic proteins Bcl-XL and XIAP, using actin as a loading control. PARP, poly(ADP-ribose) polymerase; TRAIL, tumor necrosis factor-related apoptosis-inducing ligand; Bcl-XL, B-cell lymphoma-extra large; XIAP, X-linked inhibitor of apoptosis protein

death-receptor-mediated apoptosis-inducing effect of the extract in a combination treatment with another ligand of death receptors, TRAIL, was investigated. Treatment of the HeLa cells by up to $200 \mathrm{ng} / \mathrm{ml}$ of TRAIL for $24 \mathrm{~h}$ was reported to have little effect on cell death $(<20 \%)(30,31)$. Therefore, the concentration of TRAIL was fixed at $200 \mathrm{ng} / \mathrm{ml}$ for all TRAIL studies. Pretreatment with the ethanolic extract of T. peruviana flowers (3-300 $\mu \mathrm{g} / \mathrm{ml})$ for $30 \mathrm{~min}$, followed by TRAIL stimulation for $24 \mathrm{~h}$, enhanced TRAIL-induced cell death. The significant enhancement was observed when 10-300 $\mu \mathrm{g} / \mathrm{ml}$ of the extract was combined with TRAIL (Fig. 5). The combination treatment of TRAIL and $10-300 \mu \mathrm{g} / \mathrm{ml}$ of the ethanolic extract of T. peruviana flowers increased the percentage of cell death significantly, up to $80 \%$. However, the extract was selected at the concentration of $10 \mu \mathrm{g} / \mathrm{ml}$ for further study, as it was the minimum concentration that significantly increased the percentage of cell death $>80 \%$ when combined with TRAIL (Fig. 5). Typical morphological changes of apoptotic cell death were observed by microscopy. Massive cell death was observed at $12 \mathrm{~h}$ in the HeLa cells treated with the combination of $10 \mu \mathrm{g} / \mathrm{ml}$ extract and $200 \mathrm{ng} / \mathrm{ml}$ TRAIL (Fig. 6A). In addition, the apoptosis-inducing effect of TRAIL was enhanced markedly when the HeLa cells were pretreated with $10 \mu \mathrm{g} / \mathrm{ml}$ extract, as shown by the increased cleavage of Bid, caspase-3 and PARP (Fig. 6B).

Downregulation of anti-apoptotic protein Bcl-XL mediates the TRAIL sensitization effect of the ethanolic extract of T. peruviana flowers. Treatment of the HeLa cells with the ethanolic extract of $T$. peruviana flowers alone or in combination with TRAIL for $3 \mathrm{~h}$ selectively decreased the level of anti-apoptotic protein Bcl-XL in a dose-dependent manner (Fig. 7). The combination treatment of the ethanolic extract of T. peruviana flowers at $10 \mu \mathrm{g} / \mathrm{ml}$ and TRAIL exhibited a marked decrease in the anti-apoptotic protein Bcl-XL level, similar to that observed with the combination treatment of the ethanolic extract of T. peruviana flowers at $100 \mu \mathrm{g} / \mathrm{ml}$ and 
TNF- $\alpha$, while the level of XIAP was less affected (Fig. 7). These results indicated that the ethanolic extract of $T$. peruviana flowers sensitized death receptor-induced apoptosis by the downregulation of anti-apoptotic protein Bcl-XL.

\section{Discussion}

The use of death receptor-mediated cancer cell death alone or in combination with chemotherapeutic drugs is considered as a novel approach for cancer therapy, particularly for the treatment of chemotherapeutic drug-resistant cancer. TNF- $\alpha$ and TRAIL are ligands of the TNF family, and are capable of apoptosis induction through the engagement of their death receptors (9-13). It was previously found that the combination of chemotherapeutic drugs and TNF- $\alpha$ or TRAIL amplified the apoptosis signal and sensitized resistant cancers to apoptosis (32-35). The TRAIL sensitization effect of thevefolin cardenolide glycoside isolated from the bark extract of $T$. peruviana was previously reported (27), but the underlying mechanism has not been elucidated until now. The present study demonstrated the mechanisms behind the apoptosis-enhancing effects of the ethanolic extract of T. peruviana flowers that overcomes the TNF- $\alpha$ and TRAIL resistance of HeLa cells.

It was demonstrated that the ethanolic extract of T. peruviana flowers enhanced the TNF- $\alpha$ - and TRAIL-induced apoptosis of the HeLa cells. It was also demonstrated that the activation of the caspase cascade, PARP and Bid cleavage, and the downregulation of anti-apoptotic proteins, including Mcl-1, XIAP, survivin and Bcl-XL, are the mechanisms for the enhancement of the TNF- $\alpha$ - and TRAIL-induced apoptosis by the ethanolic extract of $T$. peruviana flowers. In the extrinsic signaling pathway, the caspase cascade causes apoptosis signal transduction through death receptor activation after death receptor ligand binding (1). TNF- $\alpha$ binds to its receptor, TNF-R1, and recruits TRADD and FADD, which activate caspase- 8 . Activated caspase- 8 subsequently activates caspase- -3 , resulting in the cleavage of cellular proteins and apoptotic cell death $(9,10)$. TRAIL binds to the death receptors, DR4 and DR5, leading to the clustering of intracellular death domains and the subsequent formation of the death-inducing signaling complex (DISC). Trimerization of the death domain leads to the recruitment of an adaptor molecule, FADD, and subsequent activation of caspase- 8 and caspase- 10 , which in turn leads to the cleavage of caspase-3 and death substrates $(9,11,12)$. Previous studies indicated that TNF- $\alpha$ induced cell death through caspase-3 activation and PARP cleavage $(36,37)$. It has been reported that caspase- 8 activation was observed in the TRAIL-induced apoptosis of HeLa cancer cells $(11,31)$. In the present study, the caspase- 8 and caspase- 3 activation, and PARP cleavage by the ethanolic extract of T. peruviana flowers clearly demonstrated its apoptotic effects. Moreover, the ethanolic extract of T. peruviana flowers could enhance TNF- $\alpha$ - and TRAIL-induced apoptotic cell death in the HeLa cells. This phenomenon is consistent with a previous study showing that the extract of T. peruviana bark exhibited synergistic activity in sensitizing TRAIL-resistant cancer cells (27). The present results indicated that the enhancement of the TNF- $\alpha$ - and TRAIL-induced apoptosis of HeLa cells by the ethanolic extract of T. peruviana flowers involved the death receptor pathway.
The death receptor pathway links to the mitochondria-dependent pathway by the linker molecule Bid (13-15). In previous studies, it was reported that the cleavage of Bid by caspase- 8 triggered cytochrome $c$ release from the mitochondria to the cell cytosol followed by activation of the caspase cascade with caspase- 9 and caspase- 3 , and PARP cleavage $(36,38)$. In the present study, the combination treatment of the ethanolic extract of T. peruviana flowers and TNF- $\alpha$ or TRAIL strongly promoted Bid cleavage, while the treatment also enhanced caspase- 9 and caspase- 3 cleavage. The results indicated that the mitochondria-dependent pathway also participated in the enhancing effect of the TNF- $\alpha$ - and TRAIL-induced apoptosis of the ethanolic extract of T. peruviana flowers.

In the apoptosis signaling pathway, anti-apoptotic proteins, including Bcl-XL, Mcl-1, XIAP and survivin, are survival factors, playing a major role in apoptosis suppression. Previous reports indicated that apoptosis could be enhanced by the downregulation of Bcl-XL, Mcl-1, XIAP and survivin (18,39-42). Likewise, previous studies reported that the inhibition of Bcl-XL, Mcl-1, XIAP and survivin enhanced the sensitization of HeLa cells to death receptor-induced apoptosis $(30,36)$. The present results clearly showed that the combination treatment of the ethanolic extract of T.peruviana flowers and TNF- $\alpha$ downregulated the expression of Mcl-1, Bcl-XL, XIAP and survivin, while the combination treatment with TRAIL downregulated the expression of Bcl-XL. Moreover, Bcl-XL downregulation was sufficient to sensitize the HeLa cells to TRAIL-induced apoptosis. It was possible that the ethanolic extract of $T$. peruviana flowers induced Bid cleavage and caspase- 9 activation in a Bcl-XL-sensitive manner, as shown by the increase in the degradation of caspase-9 together with the decrease in Bid and Bcl-XL expression. In the death receptor pathway, nuclear factor- $\mathrm{\kappa} B$ $(\mathrm{NF}-\mathrm{\kappa B})$, a well-known transcription factor, protects cells from apoptosis by the activation of survival factors such as anti-apoptotic proteins (43). It has been shown in HeLa cells that the inhibition of NF- $\mathrm{KB}$ can sensitize the cancer cells to TNF- $\alpha$ - and TRAIL-induced apoptosis $(29,31,37)$. The present results showed that the ethanolic extract of T. peruviana flowers had no effect on TNF- $\alpha$-induced NF- $\mathrm{KB}$ activation (data not shown). Therefore, the enhancement of the TNF- $\alpha$ - and TRAIL-induced apoptosis in HeLa cells by the ethanolic extract of T. peruviana flowers was, at least in part, due to the downregulation of Bcl-XL expression.

Although the present results showed that the ethanolic extract of T. peruviana flowers sensitized TRAIL-resistant HeLa cells by downregulating Bcl-XL expression when combined with TNF- $\alpha$ or TRAIL, it has been shown that other anti-apoptotic signaling pathways, including the phosphoinositide 3-kinase/Akt and mitogen-activated protein kinases pathways, are involved in TRAIL resistance (31). For future studies, it is necessary to investigate the mechanisms of action of the ethanolic extract of T. peruviana flowers on these anti-apoptotic signaling pathways, so that the TNF- $\alpha$ and TRAIL sensitization effect of the ethanolic extract of T. peruviana flowers can be clearly clarified. In addition, the effect of the ethanolic extract of T. peruviana flowers on death receptor-induced apoptosis should be studied in other TRAIL-resistant human cancer cells, such as the human lung 
cancer A549 cell line, to confirm its ability as a sensitizer of death receptor-induced apoptosis in TRAIL-resistant cancer cells.

In conclusion, the ethanolic extract of T. peruviana flowers sensitized HeLa cells to TNF- $\alpha$ - and TRAIL-induced apoptosis via the intrinsic and extrinsic pathways by the activation of the caspase cascade, Bid and PARP cleavage. The ethanolic extract of $T$. peruviana flowers enhanced TNF- $\alpha$-induced apoptosis through the downregulation of Mcl-1, Bcl-XL, XIAP and survivin, while the ethanolic extract of T.peruviana flowers enhanced TRAIL-induced apoptosis through the downregulation of Bcl-XL.

\section{Acknowledgements}

This study was supported by a Japanese-Thai Collaborative Scientific Research Fellowship (JSPS-NRCT 2009 and 2010, I. Saiki, Institute of Natural Medicine). The authors would like to thank Assistant Professor Pongtip Sithisarn (Department of Pharmacognosy, Faculty of Pharmacy, Mahidol University, Bangkok, Thailand), Dr Kriengsak Lirdprapamongkol (Laboratory of Biochemistry, Chulabhorn Research Institute, Bangkok, Thailand) and Dr Vipaporn Sareedenchai (Department of Pharmacognosy, Faculty of Pharmacy, Srinakharinwirot University, Nakhonnayok, Thailand) for their valuable suggestions.

\section{References}

1. Fulda S and Debatin KM: Extrinsic versus intrinsic apoptosis pathways in anticancer chemotherapy. Oncogene 25: 4798-4811, 2006.

2. Morales-Cano D, Calviño E, Rubio V, Herráez A, Sancho P, Tejedor MC and Diez JC: Apoptosis induced by paclitaxel via Bcl-2, Bax and caspases 3 and 9 activation in NB4 human leukaemia cells is not modulated by ERK inhibition. Exp Toxicol Pathol 65: 1101-1108, 2013.

3. Huang CR, Jin ZX, Dong L, Tong XP, Yue S, Kawanami T, Sawaki T, Sakai T, Miki M, Iwao H, et al : Cisplatin augments FAS-mediated apoptosis through lipid rafts. Anticancer Res 30: 2065-2071, 2010.

4. Lee HH, Ye S, Li XJ, Lee KB, Park MH and Kim SM: Combination treatment with paclitaxel and doxorubicin inhibits growth of human esophageal squamous cancer cells by inactivation of Akt. Oncol Rep 31: 183-188, 2014.

5. Kim CW, Lu JN, Go SI, Jung JH, Yi SM, Jeong JH, Hah YS, Han MS, Park JW, Lee WS and Min YJ: P53 restoration can overcome cisplatin resistance through inhibition of Akt as well as induction of Bax. Int J Oncol 43: 1495-1502, 2013.

6. Chee JL, Saidin S, Lane DP, Leong SM, Noll JE, Neilsen PM, Phua YT, Gabra H and Lim TM: Wild-type and mutant p53 mediate cisplatin resistance through interaction and inhibition of active caspase-9. Cell Cycle 12: 278-288, 2013.

7. El-Deiry WS: Insights into cancer therapeutic design based on p53 and TRAIL receptor signaling. Cell Death Differ 8: 1066-1075, 2001.

8. Micheau O, Hammann A, Solary E and Dimanche-Boitrel MT: STAT-1-Independent upregulation of FADD and procaspase-3 and -8 in cancer cells treated with cytotoxic drugs. Biochem Biophys Res Commun 256: 603-607, 1999.

9. Pobezinskaya YL and Liu Z: The role of TRADD in death receptor signaling. Cell Cycle 11: 871-876, 2012.

10. Baud V and Karin M: Signal transduction by tumor necrosis factor and its relatives. Trends Cell Biol 11: 372-377, 2001.

11. Wang S and El-Deiry WS: TRAIL and apoptosis induction by TNF-family death receptors. Oncogene 22: 8628-8633, 2003

12. Sessler T, Healy S, Samali A and Szegezdi E: Structural determinants of DISC function: New insights into death receptor-mediated apoptosis signalling. Pharmacol Ther 140: 186-199, 2013.
13. Werner AB, de Vries E, Tait SW, Bontjer I and Borst J: TRAIL receptor and CD95 signal to mitochondria via FADD, caspase-8/10, Bid, and Bax but differentially regulate events downstream from truncated Bid. J Biol Chem 277: 40760-40767, 2002.

14. Yin XM: Signal transduction mediated by Bid, a pro-death Bcl-2 family proteins, connects the death receptor and mitochondria apoptosis pathways. Cell Res 10: 161-167, 2000.

15. Schug ZT, Gonzalvez F, Houtkooper RH, Vaz FM and Gottlieb E: BID is cleaved by caspase- 8 within a native complex on the mitochondrial membrane. Cell Death Differ 18: 538-548, 2011.

16. Boucher D, Blais V and Denault JB: Caspase-7 uses an exosite to promote poly (ADP ribose) polymerase 1 proteolysis. Proc Natl Acad Sci USA 109: 5669-5674, 2012.

17. Soldani C and Scovassi AI: Poly (ADP-ribose) polymerase-1 cleavage during apoptosis: An update. Apoptosis 7: 321-328, 2002.

18. Chawla-Sarkar M, Bae SI, Reu FJ, Jacobs BS, Lindner DJ and Borden EC: Downregulation of Bcl-2, FLIP or IAPs (XIAP and survivin) by siRNAs sensitizes resistant melanoma cells to Apo2L/TRAIL-induced apoptosis. Cell Death Differ 11: 915-923, 2014.

19. Lamothe B and Aggarwal BB: Ectopic expression of Bcl-2 and Bcl-xL inhibits apoptosis induced by TNF-related apoptosis-inducing ligand (TRAIL) through suppression of caspases-8, 7 , and 3 and BID cleavage in human acute myelogenous leukemia cell line HL-60. J Interferon Cytokine Res 22: 269-279, 2002.

20. Fas SC, Baumann S, Zhu JY, Giaisi M, Treiber MK, Mahlknecht U, Krammer PH and Li-Weber M: Wogonin sensitizes resistant malignant cells to TNFalpha-and TRAIL-induced apoptosis. Blood 108: 3700-3706, 2006.

21. Abdelhamed S, Yokoyama S, Hafiyani L, Kalauni SK, Hayakawa Y, Awale S and Saiki I: Identification of plant extracts sensitizing breast cancer cells to TRAIL. Oncol Rep 29: 1991-1998, 2013.

22. Bandara V, Weinstein SA, White J and Eddleston M: A review of the natural history, toxinology, diagnosis and clinical management of Nerium oleander (common oleander) and Thevetia peruviana (yellow oleander) poisoning. Toxicon 56: 273-281, 2010.

23. Kohls S, Scholz-Böttcher BM, Teske J, Zark P and Rullkötter J: Cardiac glycosides from Yellow Oleander (Thevetia peruviana) seeds. Phytochemistry 75: 114-127, 2012.

24. Srivastava N, Chauhan AS and Sharma B: Isolation and characterization of some phytochemicals from Indian traditional plants. Biotechnol Res Int 2012: 549850, 2012.

25. Gata-Gonçalves L, Nogueira JM, Matos O and Bruno de Sousa R: Photoactive extracts from Thevetia peruviana with antifungal properties against Cladosporium cucumerinum. J Photochem Photobiol B 70: 51-54, 2003.

26. Tewtrakul S, Nakamura N, Hattori M, Fujiwara T and Supavita T: Flavanone and flavonol glycosides from the leaves of Thevetia peruviana and their HIV-1 reverse transcriptase and HIV-1 integrase inhibitory activities. Chem Pharm Bull (Tokyo) 50: 630-635, 2002.

27. Miyagawa T, Ohtsuki T, Koyano T, Kowithayakorn T and Ishibashi M: Cardenolide glycosides of Thevetia peruviana and triterpenoid saponins of Sapindus emarginatus as TRAIL resistance-overcoming compounds. J Nat Prod 72: 1507-1511, 2009.

28. Lirdprapamongkol K, Sakurai H, Kawasaki N, Choo MK, Saitoh Y, Aozuka Y, Singhirunnusorn P, Ruchirawat S, Svasti J and Saiki I: Vanillin suppresses in vitro invasion and in vivo metastasis of mouse breast cancer cells. Eur J Pharm Sci 25: 57-65, 2005.

29. Lirdprapamongkol K, Sakurai H, Suzuki S, Koizumi K, Prangsaengtong O, Viriyaroj A, Ruchirawat S, Svasti J and Saiki I: Vanillin enhances TRAIL-induced apoptosis in cancer cells through inhibition of NF-kappaB activation. In Vivo 24: 501-506, 2010.

30. Lirdprapamongkol K, Sakurai H, Abdelhamed S, Yokoyama S, Athikomkulchai S, Viriyaroj A, Awale S, Ruchirawat S, Svasti J and Saiki I: Chrysin overcomes TRAIL resistance of cancer cells through Mcl-1 downregulation by inhibiting STAT3 phosphorylation. Int J Oncol 43: 329-337, 2013.

31. Thanaketpaisarn O, Waiwut P, Sakurai H and Saiki I: Artesunate enhances TRAIL-induced apoptosis in human cervical carcinoma cells through inhibition of the NF- $\kappa \mathrm{B}$ and PI3K/Akt signaling pathways. Int J Oncol 39: 279-285, 2011.

32. Cuello M, Ettenberg SA, Nau MM and Lipkowitz S: Synergistic induction of apoptosis by the combination of trail and chemotherapy in chemoresistant ovarian cancer cells. Gynecol Oncol 81: 380-390, 2001. 
33. Lagadec C, Adriaenssens E, Toillon RA, Chopin V, Romon R, Van Coppenolle F, Hondermarck H and Le Bourhis X: Tamoxifen and TRAIL synergistically induce apoptosis in breast cancer cells. Oncogene 27: 1472-1477, 2008.

34. Chopin V, Slomianny C, Hondermarck H and Le Bourhis X: Synergistic induction of apoptosis in breast cancer cells by cotreatment with butyrate and TNF-alpha, TRAIL, or anti-Fas agonist antibody involves enhancement of death receptors' signaling and requires P21 (waf1). Exp Cell Res 298: 560-573, 2004.

35. Kim DM, Koo SY, Jeon K, Kim MH, Lee J, Hong CY and Jeong S: Rapid induction of apoptosis by combination of flavopiridol and tumor necrosis factor (TNF)-alpha or TNF-related apoptosis-inducing ligand in human cancer cell lines. Cancer Res 63: 621-626, 2003.

36. Waiwut P, Inujima A, Inoue $H$, Saiki I and Sakurai H: Bufotalin sensitizes death receptor-induced apoptosis via Bidand STAT1-dependent pathways. Int J Oncol 40: 203-208, 2012.

37. Waiwut P, Shin MS, Inujima A, Zhou Y, Koizumi K, Saiki I and Sakurai H: Gomisin N enhances TNF- $\alpha$-induced apoptosis via inhibition of the NF- $\kappa \mathrm{B}$ and EGFR survival pathways. Mol Cell Biochem 350: 169-175, 2011.
38. Liu L, Yim H, Choi JH, Kim ST, Jin Y and Lee SK: ATM kinase promotes both caspase- 8 and caspase-9 activation during TNF- $\alpha$-induced apoptosis of HeLa cells. FEBS Lett 588: 929-935, 2014

39. Kim EH, Kim SU, Shin DY and Choi KS: Roscovitine sensitizes glioma cells to TRAIL-mediated apoptosis by downregulation of survivin and XIAP. Oncogene 23: 446-456, 2004.

40. Zhu H, Guo W, Zhang L, Davis JJ, Wu S, Teraishi F, Cao X, Smythe WR and Fang B: Enhancing TRAIL-induced apoptosis by Bcl-XL siRNA. Cancer Biol Ther 4: 393-397, 2005.

41. Dong Y, Yin S, Li J, Jiang C, Ye M and Hu H: Bufadienolide compounds sensitize human breast cancer cells to TRAIL-induced apoptosis via inhibition of STAT3/Mcl-1 pathway. Apoptosis 16: 394-403, 2011.

42. Kim JY, Kim EH, Kim SU, Kwon TK and Choi KS: Capsaicin sensitizes malignant glioma cells to TRAIL-mediated apoptosis via DR5 upregulation and survivin downregulation. Carcinogenesis 31: 367-375, 2010

43. Bui NT, Livolsi A, Peyron JF and Prehn JH: Activation of nuclear factor kappaB and $\mathrm{Bcl}-\mathrm{x}$ survival gene expression by nerve growth factor requires tyrosine phosphorylation of IkappaBalpha. J Cell Biol 152: 753-764, 2001. 